\title{
Speciation of nickel extracted from hyperaccumulator plants by water leaching
}

\author{
Mathilde Guilpain $^{\mathrm{a}}$, Baptiste Laubie ${ }^{\mathrm{a}}$, Xin Zhang ${ }^{\mathrm{b}}$, Jean Louis Morel ${ }^{\mathrm{c}}$, Marie-Odile Simonnot ${ }^{\mathrm{a}, *}$ \\ a Université de Lorraine, CNRS, LRGP, F-54000 Nancy, France \\ ${ }^{\mathrm{b}}$ Henan Key Laboratory for Environmental Pollution Control, Key Laboratory for Yellow River and Huai River Water Environment and Pollution Control, Ministry of \\ Education, Henan Normal University, Xinxiang 453007, China \\ ${ }^{\mathrm{c}}$ Université de Lorraine, INRA, LSE, F-54000 Nancy, France
}

\section{A R T I C L E I N F O}

\section{Keywords:}

Agromining

Nickel recovery

Alyssum murale recently renamed Odontarrhena muralis

Water leaching

Speciation at equilibrium

\begin{abstract}
A B S T R A C T
Agromining combines agronomic and hydrometallurgical processes to extract metals from secondary resources using hyperaccumulator plants (HA) and produce high value compounds. Agromining has been primarily developed for nickel (Ni) recovery from ultramafic soils. Most often, the dry HAs, containing $\mathrm{ca} 1 \mathrm{wt} \%$ of $\mathrm{Ni}$ are burnt to concentrate $\mathrm{Ni}$ in ashes (15-20 wt\%) and remove organic matter; then the ashes are treated to give $\mathrm{Ni}$ metal, oxide or salts. This work was undertaken to investigate the recovery of Ni without any combustion stage in eco-friendly conditions.

$\mathrm{Ni}$ extraction was tested with two HAs, the former grown in a temperate latitude (A. murale) the latter in a tropical climate $(R$. bengalensis), using water as an extracting agent in batch reactor, at two solid to liquid (S/L) ratios (4 and 8\%). Ni extraction yield was higher from the former HA (90\%) than from the latter (50\%). Ni concentration in the leachates increased with the S/L ratio. Therefore column experiments were run with $A$. murale to work with the highest possible $\mathrm{S} / \mathrm{L}$ ratio. Other main cations $(\mathrm{K}, \mathrm{Ca}, \mathrm{Mg}$ ) and dissolved organic compounds were solubilized as well. Knowing that $\mathrm{Ni}$ is mainly chelated by malate and citrate in the plant tissues, low molecular weight carboxylic acids (LMWCAs) were analyzed in the leachates; they accounted for $14 \%$ of the dissolved organic carbon.

The composition of the leachate at thermodynamic equilibrium was computed using the Chess software, dedicated to the simulation of the equilibrium of complex solutions, including gases, minerals, organics and colloids. Results showed that Ni was almost entirely complexed with LMWCAs. Further simulations were conducted to elucidate why $\mathrm{Ni}$ could not be simply recovered by precipitation of Ni hydroxide from the leachate. This behavior was interpreted by the contribution of a strong Ni ligand preventing the hydroxide precipitation. Calculations enabled us to obtain the minimum value of the complexation constant.

The evidence that Ni can be extracted from HAs by water leaching and a better understanding of the equilibrium of the leaching liquor are important stages for further Ni recovery and purification.
\end{abstract}

\section{Introduction}

Agromining is an emerging technology, composed of agronomic and hydrometallurgical processes designed to allow the recovery of metals from soils or secondary resources, using plants (Morel, 2013; Morel et al., 2018; Van der Ent et al., 2015, 2017b). It gives access to elements that cannot be recovered by conventional mining techniques, because of their low concentrations in the solid matrix. So far, agromining has mainly been developed for nickel (Ni). As a matter of fact, ultramafic soils, typically enriched in $\mathrm{Ni}$ and deficient in essential nutrients, cover large areas worldwide. Agromining uses hyperaccumulators (HAs) able to concentrate $\mathrm{Ni}$ in their tissues at rather high concentrations, the hyperaccumulation threshold being set at $1 \mathrm{~g}$ of $\mathrm{Ni}$ per $\mathrm{kg}$ of dry plant. More than 450 species have been documented. In temperate latitudes, they mainly belong to the Brassicaceae family, from which the plant species Alyssum murale recently renamed Odontarrhena muralis, has been widely investigated. Field experiments have proven that it can be cultivated in various countries (e.g. Albania, Greece, Spain, USA) (Bani et al., 2010; Kidd et al., 2015; Chaney et al., 2018) and yields > $100 \mathrm{~kg}$ of Ni per hectare can be achieved (Bani et al., 2015). In tropical latitudes (e.g. Malaysia), hyperaccumulators are mostly trees, like Rinorea bengalensis (Van der Ent et al., 2017a; Nkrumah et al., 2018).

\footnotetext{
* Corresponding author.

E-mail address: marie-odile.simonnot@univ-lorraine.fr (M.-O. Simonnot).
} 
Ni localization and speciation have been studied for both types of plants. A. murale accumulates $\mathrm{Ni}$ in its vacuoles while in $R$. bengalensis $\mathrm{Ni}$ is found in spongy mesophyll and in phloem at higher concentrations than in A. murale tissues (Van der Ent and Mulligan, 2015). In both cases, $\mathrm{Ni}$ is complexed by low molecular weight carboxylic acids (LMWCAs), which alleviates Ni toxicity (Callahan et al., 2006; McNear Jr et al., 2010; Montargès-Pelletier et al., 2008; Van der Ent et al., 2017a). The mechanisms of hyperaccumulation have been widely studied (Verbruggen et al., 2008) but still barely understood.

Since the early 2000's, efforts have been made to recover Ni from the biomass of HAs, to obtain Ni metal, Ni-based catalysts or Ni salts (Barbaroux et al., 2011, 2009, 2012; Chaney et al., 2007; Grison et al., 2013; Li et al., 2003). Most often, the plants are burnt to produce ashes (Simonnot et al., 2018). Ashing has several advantages: ash is a true bio-ore containing 15 to $20 \%$ of $\mathrm{Ni}$, which is higher than any $\mathrm{Ni}$ ore, without organic matter (Zhang et al., 2014), while the energy produced from burning can be recovered. $\mathrm{Ni}$ is extracted from the ash by acid leaching and separated from the other main elements to produce $\mathrm{Ni}$ compounds, for instance ANSH (ammonium and nickel sulfate hexahydrate) (Barbaroux et al., 2012; Zhang et al., 2016). This process has been studied from lab to pilot scale (Houzelot et al., 2017, 2018).

Therefore, this work was undertaken to test an alternative procedure to recover $\mathrm{Ni}$ from plant biomass, without changing the original chemical forms. To the best of our knowledge, direct extraction of $\mathrm{Ni}$ has been tested with different chemicals, acids or ligands, from $A$. murale (Barbaroux et al., 2009) and from R. bengalensis (Vaughan et al., 2017). Here, leaching is conducted with water to preserve as far as possible the original Ni-complexes, save chemicals and make the process more eco-friendly. Batch and column extraction experiments were run to assess the possibility of extracting Ni directly from the dry plants. Afterwards, Ni speciation in solution, in the presence of LMWCAs, was investigated at thermodynamic equilibrium, using Chess computer software, to calculate the composition of the solutions.

\section{Materials and methods}

\subsection{Hyperaccumulator plants}

Alyssum murale (Fig.1), recently renamed Odontarrhena muralis, is a plant from the Brassicaceae family. Plants were collected in the Progradec area (Albania) on ultramafic soils containing 3 to $7 \mathrm{mg}_{\mathrm{Ni}}\left(\mathrm{kg}_{\mathrm{dry}}\right.$ soil $)^{-1}$ (Bani et al., 2010). Harvest occurred at the flowering stage in June 2015. The aerial parts were sun-dried and $500 \mathrm{~kg}$ were ground with an industrial grinder (SECOMI) to a particle size of $2 \mathrm{~mm}$.

Rinorea bengalensis (Fig.1) is a tree from the Violaceae family, grown in Sabah (Malaysia), on ultramafic soils containing about $3 \mathrm{mg}_{\mathrm{Ni}}\left(\mathrm{kg}_{\mathrm{dry}}\right.$ soil) $)^{-1}$ (Galey et al., 2017). A few kilograms of leaves were collected in March 2017. They were sun-dried and ground in the lab with a blade grinder (Seb type 8100) to particle sizes between 0.1 and $0.4 \mathrm{~mm}$.

Both ground materials were stored at room temperature $\left(20^{\circ} \mathrm{C}\right)$, the relevant amounts were taken and dried overnight at $100^{\circ} \mathrm{C}$ (Heat chamber Hareaus Instruments Typ T6) before experiments.

\subsection{Chemicals}

Malic acid ( $>99 \%$ ), malonic acid ( $>98 \%$ ) and hydrogeno-phtalate (analytical grade) were provided by Fluka, citric acid $(>99.5 \%)$ and oxalic acid $(>99,5 \%)$ by Labkem, Ni acetate $(>99 \%)$ by Acros organics, $\mathrm{NaOH}(97-100,5 \%)$ by Carlo Erba, $\mathrm{NHO}_{3}$ (>65\%) by Sigma Aldrich and $\mathrm{H}_{2} \mathrm{O}_{2}(>50 \%)$ by VWR. Ultra-pure water (Elga - Purelab Chorus) was used for all the experiments.

\subsection{Leaching experiments}

\subsubsection{Batch experiments}

The ground plants were leached with $50 \mathrm{~mL}$ of ultra-pure water in beakers of $100 \mathrm{~mL}$ at a pulp density of 4 or $8 \%$, at $20^{\circ} \mathrm{C}$. Leaching was proceeded during $15 \mathrm{~min}$ under stirring. A magnetic stirrer was used at the pulp density of $4 \%$, but a glass rod was needed at $8 \%$ to improve mixing. Solid and liquid fractions were separated by vacuum filtration (Phenomenex, cellulose regenerated filter, $47 \mathrm{~mm}$ disks, pore size $8 \mu \mathrm{m}$ ) before analysis.

To monitor kinetics, leaching was performed with $40 \mathrm{~g}$ of ground plants and $1 \mathrm{~L}$ of ultra-pure water in a $2 \mathrm{~L}$ beaker, under magnetic agitation. Aliquots of $15 \mathrm{~mL}$ were sampled every 5 min during $30 \mathrm{~min}$ and filtered as previously before analysis.

Reflux extractions were also performed from A. murale with water heated at $100{ }^{\circ} \mathrm{C}$ at a pulp density of $4 \%$. Two $g$ of ground-dried plants were placed into a $100 \mathrm{~mL}$ round-bottom flask with $50 \mathrm{~mL}$ of ultra-pure water. A condenser was placed on the flask and the system heated with an oil bath at $100{ }^{\circ} \mathrm{C}$. Extraction lasted $15 \mathrm{~min}$ counted from boiling.

\subsubsection{Column experiments}

The experimental set up was composed of a syringe pump, a glass column (GE Healthcare Life Science XK 50/20, 20*5 cm id), on line pH (electrode Mettler Toledo, 1-11 pH, 0-80 ${ }^{\circ} \mathrm{CT}$, Standard $\mathrm{pH}$ Meter Materlab PH210) and conductivity detectors and a fraction collector (Gilson 206 Fraction collector) (Fig. 1). A mass of $60 \mathrm{~g}$ of ground plants was introduced into the column (bed height: $13 \mathrm{~cm}$, bed volume (BV): $255 \mathrm{~mL}$ ). The column was fed with ultra-pure water upwards at a flow rate of $450 \mathrm{~mL} \mathrm{~h}^{-1}\left(1.76 \mathrm{BV} \mathrm{h}^{-1}\right)$.

\subsection{Selective precipitation}

Selective precipitation was performed by adding $10 \mathrm{M}$ sodium hydroxide to an aliquot of $200 \mathrm{~mL}$ of leachate, prepared as described in Section 2.3.2, under magnetic stirring, until reaching $\mathrm{pH} 13 . \mathrm{pH}$ was continuously measured (electrode Hamilton Filtrode, 0-14 pH, $0-60{ }^{\circ} \mathrm{CT}$, Standard $\mathrm{pH}$ Meter Materlab PH210). The suspension was then filtered as previously before analysis.

\subsection{Analysis}

\subsubsection{Elemental composition}

Solid samples $(0.1 \mathrm{~g})$ were digested with $8.5 \mathrm{~mL}$ of $\mathrm{HNO}_{3}$ and $1.5 \mathrm{~mL}$ of $\mathrm{H}_{2} \mathrm{O}_{2}$ in a microwave oven (Milestone Start D Microwave Digestion

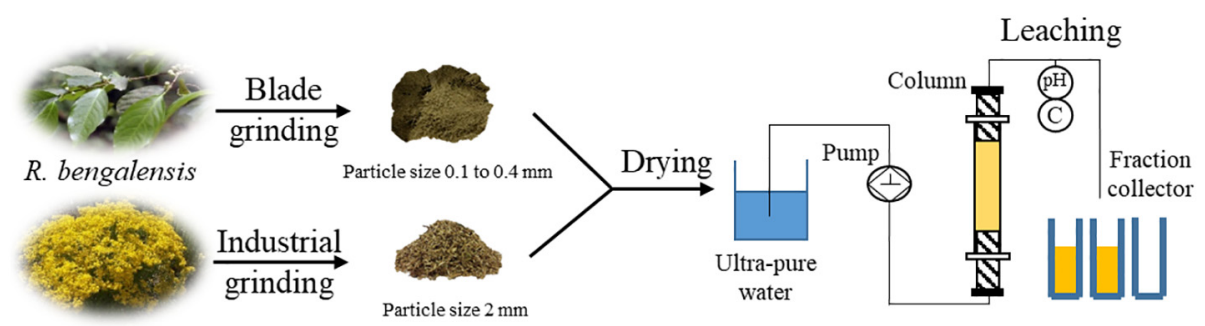

A. murale

Fig. 1. Scheme on the packed bed column experiment. 
System). Digestion was performed as follows: temperature increase to $120^{\circ} \mathrm{C}$ during $10 \mathrm{~min}$, then to $180^{\circ} \mathrm{C}$ during $10 \mathrm{~min}$ and a stage at $180^{\circ} \mathrm{C}$ during $15 \mathrm{~min}$. Liquid samples $(2 \mathrm{~mL})$ were digested with $1 \mathrm{~mL}$ of $\mathrm{HNO}_{3}$ (temperature was increased to $180^{\circ} \mathrm{C}$ during 15 min and kept at $180^{\circ} \mathrm{C}$ during $10 \mathrm{~min}$ ). Digestates were diluted to $50 \mathrm{~mL}$ with ultra-pure water and filtered (Phenomenex, regenerated cellulose, $25 \mathrm{~mm}$ disks, pore size $0.45 \mu \mathrm{m})$.

Samples were analyzed by plasma emission spectroscopy (ICP-AES) (Thermo ICAP 6000 Series ICP Spectrometer). Quality controls were performed with standard solutions prepared from a multi-element certified solution ( $1000 \mathrm{mg} \mathrm{L}^{-1}$ SCP sciences).

\subsubsection{Dissolved organic carbon (DOC)}

Liquid samples $(40 \mathrm{~mL})$ were analyzed by an organic carbon analyzer TOC- $\mathrm{V}_{\mathrm{CSH}}$ (Shimadzu). Hydrogeno-phtalate was used for standardization.

\subsubsection{Low molecular weight carboxylic acids (LMWCAs)}

LMWCAs were analyzed by HPLC (Shimadzu, prominence modular, 20A series). HPLC conditions were as follows: Kinetex F5 column (100*4.6 mm id, packing diameter: $2.6 \mu \mathrm{m})$ in series with an Aminex HPX $87 \mathrm{H}$ column $(300 * 7.8 \mathrm{~mm}$ id, packing diameter: $9 \mu \mathrm{m})$; diode array detector at $214 \mathrm{~nm}$; mobile phase: $\mathrm{H}_{2} \mathrm{SO}_{4} 2 \mathrm{mM}$ at $0.3 \mathrm{~mL} \mathrm{~min}^{-1}$, $60 \mathrm{~min}$ isocratic mode, temperature $30^{\circ} \mathrm{C}$. Standardization was performed with a solution containing malic, malonic, citric, oxalic acids and nickel acetate salts, at concentrations range from 0.5 to $10 \mathrm{mM}$ for each species.

\subsection{Nickel speciation modeling}

Nickel speciation was calculated using the Chess software (Chemical Equilibrium of Species and Surfaces, version 4.0.5, Mines ParisTech) designed to perform a variety of aqueous geochemical calculations, to determine the equilibrium state of multicomponent systems (Van der Lee and De Windt, 2002). Concentrations and $\mathrm{pH}$ can be fixed or variable, which enables us to observe the effect of the variation of one parameter on the speciation. In order to calculate the composition of the present systems, the database used was the Chess-formatted version of EQ3/6, initially supplied with the software, containing 1200 aqueous species including 98 redox couples, 1126 minerals, 91 gases, 74 types of adsorption sites, 3 inorganic colloids and 3 organic colloids. Metal carboxylate complex constants were missing, therefore the database was completed by the values of thermodynamic stability constants found in the Critical database to input carboxylate complexes (Martell et al., 1997) The following metals were added: $\mathrm{Li}, \mathrm{Na}, \mathrm{K}, \mathrm{Mg}, \mathrm{Co}, \mathrm{Ni}, \mathrm{Cu}$ and $\mathrm{Zn}$ as well as the following ligands: acetate, citrate, formate, fumarate, lactate, malate, maleate, malonate, oxalate, pyruvate, succinate and tartrate. The complexation constants relevant to our experimentation are listed in Table 1. They refer to the general chemical reaction described by Eq. (1):

$x A^{m+}+y B^{n-} \leftrightarrow\left(A_{x} B_{y}\right)^{(x * m-y * n)}$

where $\mathrm{A}^{\mathrm{m}+}$ and $\mathrm{B}^{\mathrm{n}-}$ are the reactants, and $\mathrm{A}_{\mathrm{x}} \mathrm{B}_{\mathrm{y}}{ }^{\left(\mathrm{x}_{*} \mathrm{~m}-\mathrm{y} * \mathrm{n}\right)}$ the formed complex, with a formation constant expressed as in Eq. (2):

$K=\frac{\left[\left(A_{x} B_{y}\right)^{(x * m-y * n)}\right]}{\left[x A^{m+}\right] *\left[y B^{n-}\right]}$

In the database, formation constants were input at zero ionic strength and at $25{ }^{\circ} \mathrm{C}$; the truncated Davies formulation is used for nonideality correction.

The user has to input the total concentrations of each element present in the solution, as well as the needed physico-chemical parameters (e.g. $\mathrm{pH}$ and temperature). Then the program selects all the possible reactions of the database in which the elements are involved and the system of equations is solved, including mass action laws and mass and charge conservation. Results are given as a list of chemical species and concentrations in the liquid, solid and gas phases at thermodynamic equilibrium. The accuracy of the calculations depends on two main hypothesis: 1) all the involved species and reactions are taken into account (or, in other words, are listed in the database) and 2) the system is really at thermodynamic equilibrium (not limited by chemical kinetics or mass transfer).

\section{Results and discussions}

\subsection{Biomass composition}

The entirety of the aerial parts of A. murale (stems, leaves plus flowers) was tested. Among the main cations, $\mathrm{K}$ was the major element, followed by Ni, Ca, Mg and Fe (Table 2). Zhang et al. (2014) obtained comparable results but the concentrations measured by Barbaroux et al. (2012) were higher (e.g. $9.73 \pm 1.22 \mathrm{~g} \mathrm{~kg}^{-1}$ for Ni). Actually the concentrations of minerals in the plants are related to soil type, localization and composition (Bani et al., 2013).

For $R$. bengalensis, only limited amounts of leaves were studied. The concentrations of the major cations were $c a 2$ to 5 times higher than for A. murale and no Fe was detected (Table 2). They were in the same range as obtained by Vaughan et al. (2017), even if the plants had not been collected at the same location and time.

\subsection{Nickel leaching by water in batch reactors}

\subsubsection{Choice of the operating conditions}

Preliminary experiments were performed to monitor leaching kinetics; a typical curve is shown in supplementary materials (S1). The monitored metals exhibited identical behavior: their concentration in solution increased to reach an asymptote at $c a 10 \mathrm{~min}$; hence a contact time of 15 min was chosen.

The S/L ratio was increased from 4 to $8 \%$; this value could not be increased, because of difficulties in mixing. At a higher ratio, the plants were not correctly immersed and had a tendency to float.

\subsubsection{Extraction yields of the major cations}

The extraction yield of element $\mathrm{i}$ is defined following Eq. (3):

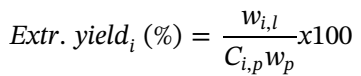

where $w_{i, 1}$ is the mass of element $i$ in solution after leaching $(g), C_{i, p}$ the concentration of $i$ in the plant tissues ( $g$ of $i\left(g_{\text {dry plant }}\right)^{-1}$ ) and $w_{p}$ the mass of dry plant in the batch reactor $(\mathrm{g})$.

Fig. 2 presents the extraction yields obtained with $A$. murale and $R$. bengalensis at $\mathrm{S} / \mathrm{L}$ ratios of 4 and $8 \%$ at $20^{\circ} \mathrm{C}$.

Extractions at $100{ }^{\circ} \mathrm{C}$ were not significantly more efficient than at $20^{\circ} \mathrm{C}$ (results not shown). The extraction yield of Ni was only increased by $3 \%$; therefore, in order to save energy and facilitate further upscaling, the temperature of $20^{\circ} \mathrm{C}$ was chosen.

The extraction yields of all elements were higher with $A$. murale than with $R$. bengalensis (Fig. 2). The extraction yields of $\mathrm{K}$ and $\mathrm{Mg}$ were comparable for both plants. However the extraction of $\mathrm{Ni}$ and $\mathrm{Ca}$ were drastically different. At a S/L ratio of $4 \%, 90 \%$ of the $\mathrm{Ni}$ and $>50 \%$ of the Ca were extracted from $A$. murale. Lower extraction rates were recorded from $R$. bengalensis, ca $50 \%$ of the $\mathrm{Ni}$ and $10 \%$ of the Ca. For both plants, nearly the same yields were obtained at both S/L ratios. The concentration of the major elements in the leach liquors of both plants are listed in Table 2.

The ability of a given element to be leached depends on its status in plant tissues. Ni is mainly complexed by low molecular weight carboxylic acids: malate and citrate in A. murale (Alves et al., 2011; Centofanti et al., 2013; Kersten et al., 1980; Montargès-Pelletier et al., 2008) and malate in R. bengalensis (Van der Ent et al., 2017a). But its localization depends on the plant. In A. murale, $\mathrm{Ni}$ is transported to the 
Table 1

Example of stability constants added to the Chess-formatted version of EQ3/6 database $\left(25^{\circ} \mathrm{C}\right.$, ionic strength equal to 0$)$.

\begin{tabular}{|c|c|c|c|c|c|c|}
\hline Complex & MalateNi & MalonateNi & Citrate ${ }_{2} \mathrm{Ni}^{3-}$ & OxalateNi & Malonate ${ }_{2} \mathrm{Ni}^{2-}$ & CitrateNi ${ }^{-}$ \\
\hline Reactants & $\begin{array}{l}\text { Malate }{ }^{2-} \\
\mathrm{Ni}^{2+}\end{array}$ & $\begin{array}{l}\text { Malonate }{ }^{2-} \\
\mathrm{Ni}^{2+}\end{array}$ & $\begin{array}{l}2 \text { Citrate }^{3-} \\
\mathrm{Ni}^{2+} \mathrm{H}^{+}\end{array}$ & $\begin{array}{l}\text { Oxalate }{ }^{2-} \\
\mathrm{Ni}^{2+}\end{array}$ & $\begin{array}{l}2 \text { Malonate }^{2-} \\
\mathrm{Ni}^{2+}\end{array}$ & $\begin{array}{l}\text { Citrate }^{3-} \\
\mathrm{Ni}^{2+}\end{array}$ \\
\hline Log K & 3.90 & 4.10 & 17.23 & 7.83 & 5.72 & 5.79 \\
\hline $\begin{array}{l}\text { Complex } \\
\text { Reactants }\end{array}$ & $\begin{array}{l}\text { Citrate }_{2} \mathrm{Ni}^{4-} \\
2 \text { Citrate }^{3-} \\
\mathrm{Ni}^{2+}\end{array}$ & $\begin{array}{l}\text { MalateNi }{ }^{+} \\
\text {Malate }^{2-} \\
\mathrm{Ni}^{2+} \mathrm{H}^{+}\end{array}$ & $\begin{array}{l}\text { CitrateNi } \\
1 \mathrm{Citrate}^{3-} \\
\mathrm{Ni}^{2+} \mathrm{H}^{+}\end{array}$ & $\begin{array}{l}\text { MalonateNi }{ }^{+} \\
\text {Malonate }^{2-} \\
\mathrm{Ni}^{2+} \mathrm{H}^{+}\end{array}$ & $\begin{array}{l}\text { AcetateNi } \\
\text { Acetate }^{+-} \\
\mathrm{Ni}^{2+}\end{array}$ & $\begin{array}{l}\text { Oxalate }_{2} \mathrm{Ni}^{2-} \\
2 \text { Oxalate }^{2-} \\
\mathrm{Ni}^{2+}\end{array}$ \\
\hline $\log \mathrm{K}$ & 9.3 & 7.13 & 10.41 & 7.08 & 1.44 & 6.6 \\
\hline $\begin{array}{l}\text { Complex } \\
\text { Reactants }\end{array}$ & $\begin{array}{l}\text { CitrateNi }{ }^{+} \\
1 \text { Citrate }^{3-} \\
\mathrm{Ni}^{2+} 2 \mathrm{H}^{+}\end{array}$ & $\begin{array}{l}\text { Acetate }_{2} \mathrm{Ni} \\
2 \text { Acetate }^{-} \\
\mathrm{Ni}^{2+}\end{array}$ & $\begin{array}{l}(\text { CitrateH })_{2} \mathrm{Ni}_{2}{ }^{4-} \\
2 \text { Citrate }^{3-} \\
2 \mathrm{Ni}^{2+}-2 \mathrm{H}^{+}\end{array}$ & $\begin{array}{l}\text { MalateCa } \\
\text { Malate }^{2-} \\
\mathrm{Ca}^{2+}\end{array}$ & $\begin{array}{l}\text { MalonateCa } \\
\text { Malonate }^{2-} \\
\mathrm{Ca}^{2+}\end{array}$ & $\begin{array}{l}\text { OxalateCa } \\
\text { Oxalate } \\
\mathrm{Ca}^{2+}\end{array}$ \\
\hline $\log \mathrm{K}$ & 13.50 & 2.40 & -1.19 & 1.95 & 1.50 & 3.00 \\
\hline $\begin{array}{l}\text { Complex } \\
\text { Reactants }\end{array}$ & $\begin{array}{l}\text { AcetateCa }^{+} \\
\text {Acetate }^{-} \\
\mathrm{Ca}^{2+}\end{array}$ & $\begin{array}{l}\text { MalateCa+ } \\
\text { Malate }{ }^{2-} \\
\mathrm{Ca}^{2+} \mathrm{H}^{+}\end{array}$ & $\begin{array}{l}\text { MalonateCa } \\
\text { Malonate } \\
\mathrm{Ca}^{2+} \mathrm{H}^{+}\end{array}$ & $\begin{array}{l}\text { Oxalate }_{2} \mathrm{Ca}^{2-} \\
2 \text { Oxalate }^{2-} \\
\mathrm{Ca}^{2+}\end{array}$ & $\begin{array}{l}\text { MalateMg } \\
\text { Malate }^{2-} \\
\mathrm{Mg}^{2+}\end{array}$ & $\begin{array}{l}\text { MalonateMg } \\
\text { Malonate } \\
\mathrm{Mg}^{2+}\end{array}$ \\
\hline $\log \mathrm{K}$ & 1.18 & 6.17 & 6.20 & 2.69 & 1.71 & 2.05 \\
\hline $\begin{array}{l}\text { Complex } \\
\text { Reactants }\end{array}$ & $\begin{array}{l}\text { OxalateMg } \\
\text { Oxalate } \\
\mathrm{Mg}^{2+}\end{array}$ & $\begin{array}{l}\text { AcetateMg }^{+} \\
\text {Acetate }^{-} \\
\mathrm{Mg}^{2+}\end{array}$ & $\begin{array}{l}\text { CitrateMg } \\
\text { Citrate }^{3-} \\
\mathrm{Mg}^{2+}\end{array}$ & $\begin{array}{l}\text { Oxalate }_{2} \mathrm{Mg}^{2-} \\
2 \text { Oxalate } \\
\mathrm{Mg}^{2+}\end{array}$ & $\begin{array}{l}\text { CitrateMg } \\
\text { Citrate }^{3-} \\
\mathrm{Mg}^{2+} 2 \mathrm{H}^{+}\end{array}$ & $\begin{array}{l}\text { MalonateK }{ }^{-} \\
\text {Malonate }^{2-} \\
\mathrm{K}^{+}\end{array}$ \\
\hline $\log \mathrm{K}$ & 3.43 & 1.26 & 3.64 & 4.24 & 11.86 & 0.9 \\
\hline $\begin{array}{l}\text { Complex } \\
\text { Reactants }\end{array}$ & $\begin{array}{l}\text { MalateK } \\
\text { Malate }^{2-} \\
\mathrm{K}^{+}\end{array}$ & $\begin{array}{l}\text { AcetateK } \\
\text { Acetate }^{-} \\
\mathrm{K}^{+}\end{array}$ & $\begin{array}{l}\text { CitrateK }^{2-} \\
\text { Citrate }^{3-} \\
\mathrm{K}^{+}\end{array}$ & & & \\
\hline $\log K$ & 0.18 & -0.27 & 0.60 & & & \\
\hline
\end{tabular}

Table 2

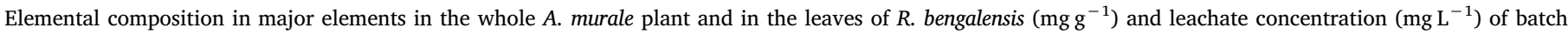
extractions for both plants.

\begin{tabular}{|c|c|c|c|c|c|c|}
\hline & \multicolumn{2}{|c|}{ Plant composition $\left(\mathrm{g} \mathrm{kg}^{-1}\right)$} & \multicolumn{4}{|c|}{ Leaching liquors composition $\left(\mathrm{mg} \mathrm{L}^{-1}\right)$} \\
\hline & \multirow[t]{2}{*}{ A. murale } & \multirow[t]{2}{*}{ R. bengalensis } & \multicolumn{2}{|l|}{ A. murale } & \multicolumn{2}{|c|}{ R. bengalensis } \\
\hline & & & $\mathrm{S} / \mathrm{L}=4 \%$ & $\mathrm{~S} / \mathrm{L}=8 \%$ & $\mathrm{~S} / \mathrm{L}=4 \%$ & $\mathrm{~S} / \mathrm{L}=8 \%$ \\
\hline $\mathrm{K}$ & $6.7 \pm 0.5$ & $12.2 \pm 0.5$ & $260 \pm 7$ & $510 \pm 15$ & $458 \pm 13$ & $808 \pm 23$ \\
\hline $\mathrm{Ni}$ & $5.1 \pm 0.7$ & $13.7 \pm 0.7$ & $190 \pm 5$ & $379 \pm 11$ & $267 \pm 8$ & $500 \pm 14$ \\
\hline $\mathrm{Ca}$ & $4.1 \pm 0.6$ & $18.5 \pm 1.2$ & $92 \pm 3$ & $178 \pm 5$ & $64 \pm 2$ & $125 \pm 4$ \\
\hline $\mathrm{Mg}$ & $2.4 \pm 0.3$ & $5.5 \pm 0.2$ & $62 \pm 2$ & $119 \pm 4$ & $135 \pm 4$ & $252 \pm 7$ \\
\hline $\mathrm{Fe}$ & $0.9 \pm 0.2$ & $\mathrm{ND}^{\mathrm{a}}$ & $\mathrm{ND}^{\mathrm{a}}$ & $2.1 \pm 0.1$ & $\mathrm{ND}^{\mathrm{a}}$ & $\mathrm{ND}^{\mathrm{a}}$ \\
\hline
\end{tabular}

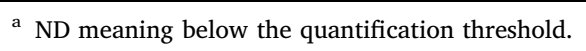

aerial parts by the xylem and once in the leaves, it is mainly stored in the epidermal vacuoles (Broadhurst et al., 2004; McNear et al., 2005; Montargès-Pelletier et al., 2008). In R. bengalensis, Ni is translocated by the xylem as well but in the leaves, it is mainly stored in the spongy mesophyll, even if a high enrichment is also observed in epidermal vacuoles (Van der Ent et al., 2017a). Vacuoles are mainly composed of water; hence Ni should be in the form of a water-soluble complex like with malate and citrate. Moreover, epidermal vacuoles are located at the leaf surface, probably making Ni more available for extraction. Spongy mesophyll is deeper in the leaves and composed of cells, where
$\mathrm{Ni}$ is stored. Cells are separated from each other by large intercellular air spaces for oxygen and carbon dioxide to diffuse, which could explain a limited transfer of $\mathrm{Ni}$ to the extraction solvent.

Concerning A. murale, water leaching had been previously tested by Zhang et al. (2014). To the best of our knowledge, it is the only case where water was used, since most often acid was preferred (Barbaroux et al., 2009). With $R$. bengalensis, Vaughan et al. (2017) have tested different extractants (ammonium and several acids) but not water at a $\mathrm{S} / \mathrm{L}$ ratio of $5 \%$, for $16 \mathrm{~h}$ at $20^{\circ} \mathrm{C}$. In these conditions, the extraction yield of $\mathrm{Ni}$ was between 43 and 59\%: the use of extractant has led to

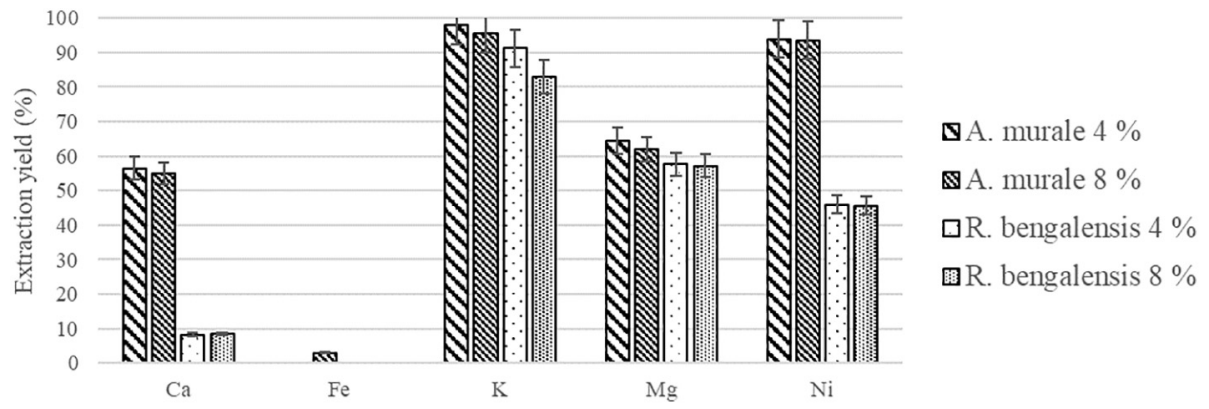

Fig. 2. Extraction yields of the major cations from $R$. bengalensis and A. murale after batch leaching at $\mathrm{S} / \mathrm{L}$ ratios of 4 and $8 \%$. 
extraction yields of the same order of magnitude as with water.

To finish, the results also show that the concentrations of the major cations in the leachates were roughly proportional to the S/L ratio (Fig. 4). Therefore, for further application, S/L ratio should be as high as possible. But practically, it is not possible in a batch reactor, as already observed (Barbaroux et al., 2009).

\subsection{Nickel leaching by water in laboratory column}

In order to increase the $\mathrm{S} / \mathrm{L}$ ratio, a laboratory column was used instead of a batch reactor. A. murale was chosen as the model plant, since the extraction yield of $\mathrm{Ni}$ was higher than with $R$. bengalensis. In the operating conditions, the S/L ratio was equal to $16 \%$ corresponding to the mass of plant in the column divided by the whole volume of collected leach liquor. The flowrate and experiment duration have been chosen (thanks to preliminary trials) at $450 \mathrm{~mL} \mathrm{~min}^{-1}$ and $52 \mathrm{~min}$. The volume flow rate corresponded to $1.76 \mathrm{BV} \mathrm{h}^{-1}$, BV being the bed volume $(255 \mathrm{~mL})$ and the experiment duration to $1.5 \mathrm{BV}$. The mean residence time previously measured was $23 \mathrm{~min}$.

\subsubsection{Elution of the major cations}

The elution curves of the major elements at the column outlet are displayed in Fig. 3. The concentrations followed the same pattern; the highest concentrations were achieved at $0.16 \mathrm{BV}: 2.0,1.5,0.8$ and $0.6 \mathrm{~g} \mathrm{~L}^{-1}$ for $\mathrm{K}, \mathrm{Ni}, \mathrm{Ca}$ and $\mathrm{Mg}$ respectively. The extraction yields were in the same range as for batch experiments: $95,87,53,61 \%$ for $\mathrm{K}, \mathrm{Ni}$, $\mathrm{Ca}$ and $\mathrm{Mg}$ respectively. The total collected volume was $370 \mathrm{~mL}$, the average concentrations $0.96,0.70,0.36$ and $0.25 \mathrm{~g} \mathrm{~L}^{-1}$ for $\mathrm{K}, \mathrm{Ni}$, Ca and $\mathrm{Mg}$ respectively at a $\mathrm{pH}$ of 5.7. Indeed, these concentrations increased linearly with the S/L ratio (Fig. 4). In this S/L range, the transfer was not limited by the chemical equilibria in solution. However, Ni extraction from the plant was not total. We assume that Ni could be bound to compounds that are not extractable with water and/or sequestrated in the solid residue.

To sum-up, static and dynamic extraction enabled us to extracts 80 to $90 \%$ of the Ni present in the tissues of A. murale, and the concentrations in the leachate increased linearly with the S/L ratio.

\subsubsection{Dissolved organic carbon}

Dissolved organic carbon $\left(\mathrm{C}_{\text {org }}\right)$ was eluted with the same pattern as the main metals. Indeed, throughout the column experiment, $\mathrm{C}_{\text {org }}$ concentration was proportional to the metal concentrations (Fig. 5), supporting the assumption that the metals are complexed with organic ligands.

In the global leachate, $\mathrm{C}_{\text {org }}$ concentration reached $12 \mathrm{gL}^{-1}$, far higher than Ni concentration, the molar ratio $\mathrm{C} / \mathrm{Ni}$ being close to 100 .

During the leaching of $A$. murale, $19 \%$ of the plant were solubilized, about $17 \%$ were organic matter, $1.4 \%$ major elements analyzed by ICP and $0.5 \%$ is $\mathrm{N}$.
It is difficult to elucidate the complete composition of the dissolved organic compounds, since many ligands may be present. Knowing that $\mathrm{Ni}$ is complexed by LMWCAs in the plant (Alves et al., 2011; Centofanti et al., 2013; Kersten et al., 1980; Montargès-Pelletier et al., 2008), these acids have been analyzed in the global leachate. The main species were malic acid, followed by malonic, citric, acetic and oxalic acids at respectively $18.93,11.84,3.61,2.48$ and $1.10 \mathrm{mmol} \mathrm{L}^{-1}$ for a Ni concentration of $9.56 \mathrm{mmol} \mathrm{L}^{-1}$. Thus, different LMWCAs of close solubility (Furia, 1973) were transferred into solution, not only the malic and citric acids, identified as the main Ni-bearing species in the plant. A balance on $C$ showed that these organic acids represent $14 \%$ of the total $\mathrm{C}_{\text {org }}$ concentration.

To compare, LMWCAs were also analyzed in the leach liquor of $R$. bengalensis obtained after batch extraction $(\mathrm{S} / \mathrm{L}=4 \%$, extraction with water during $20 \mathrm{~min}$ at $20^{\circ} \mathrm{C}$ ). The main species were malonic and malic acids at 13.18 and $4.13 \mathrm{mmol} \mathrm{L}^{-1}$ respectively, as for $A$. murale; low amounts of acetic $\left(0.17 \mathrm{mmol} \mathrm{L}^{-1}\right)$ and oxalic $\left(0.08 \mathrm{mmol} \mathrm{L}^{-1}\right)$ acids were also found for a $\mathrm{Ni}$ concentration of $4.43 \mathrm{mmol} \mathrm{L}^{-1}$. The mole ratios (sum of the LMWCAs concentrations)/(Ni concentration) was close to 4 for both plants.

\subsection{Calculation of Ni speciation in the leachate}

Despite the little knowledge of the composition of the organic matter, calculations have been run in order to improve the understanding of Ni speciation. The values of the concentrations of i) the main cations and ii) the LMWCAs were input into the Chess software, to calculate the composition at pH5.7 (Table 3). In this system, only dissociation and complexation reactions in the liquid phase are taken into account; these reactions are known to be very fast, therefore the hypothesis of thermodynamic equilibrium is reasonable.

The results give the speciation of $\mathrm{Ni}$ at thermodynamic equilibrium: $40 \%$ are complexed with malate, $25 \%$ with malonate, $17 \%$ with citrate (bidentate complex), $7 \%$ with oxalate, $4 \%$ with malonate (bidentate complex) while $3 \%$ are free (Fig. 6).

Other complexes refer to other carboxylate complexes but with different stoichiometries (e.g. CitrateNi ${ }^{-}, \mathrm{Citrate}_{2} \mathrm{Ni}^{4-}, \mathrm{MalateNi}^{+}$, MalonateNi, MalonateNi ${ }^{+}$, AcetateNi $^{+}$, Oxalate $_{2} \mathrm{Ni}^{2-}$, CitrateNi $^{+}$, Acetate ${ }_{2} \mathrm{Ni}, \mathrm{NiCl}^{+}$, Citrate $\mathrm{H}_{2} \mathrm{Ni}_{2}{ }^{4-}$ ) and some minerals $\mathrm{Ni}$ compounds (e.g. $\mathrm{Ni}_{2} \mathrm{OH}^{3+}, \mathrm{Ni}(\mathrm{OH})_{2}, \mathrm{Ni}(\mathrm{OH})^{3-}$ and $\mathrm{Ni}_{4}(\mathrm{OH})_{4}{ }^{4+}$ ) at very low concentrations (order of magnitude $10^{-10} \mathrm{mM}$ ). The speciation calculated for $\mathrm{K}, \mathrm{Ca}$ and $\mathrm{Mg}$ are provided in supplementary materials (S2).

The detailed anionic composition was not input for the calculation of the speciation but anion sensitivity was considered. High concentration in $\mathrm{S}\left(\mathrm{SO}_{4}{ }^{2-}\right), \mathrm{P}\left(\mathrm{PO}_{4}{ }^{3-}\right)$ and $\mathrm{Cl}\left(\mathrm{Cl}^{-}\right)(40 \mathrm{mM})$ were added to the data to observe their behavior regarding Ni speciation. They did not complex with $\mathrm{Ni}$ at $\mathrm{pH}$ 5.7. $\mathrm{Cl}$ was in the $\mathrm{Cl}^{-}$form at $100 \%$. $\mathrm{S}$ was in the $\mathrm{SO}_{4}{ }^{2-}$ form at $86 \%$, the remaining part being complexed by $\mathrm{Mg}(8 \%), \mathrm{K}$ (5\%) and $\mathrm{Ca}(2 \%)$. $\mathrm{P}$ was in the $\mathrm{H}_{2} \mathrm{PO}_{4}{ }^{-}$form at $85 \%$ and $\mathrm{HPO}_{4}{ }^{2-}$ at

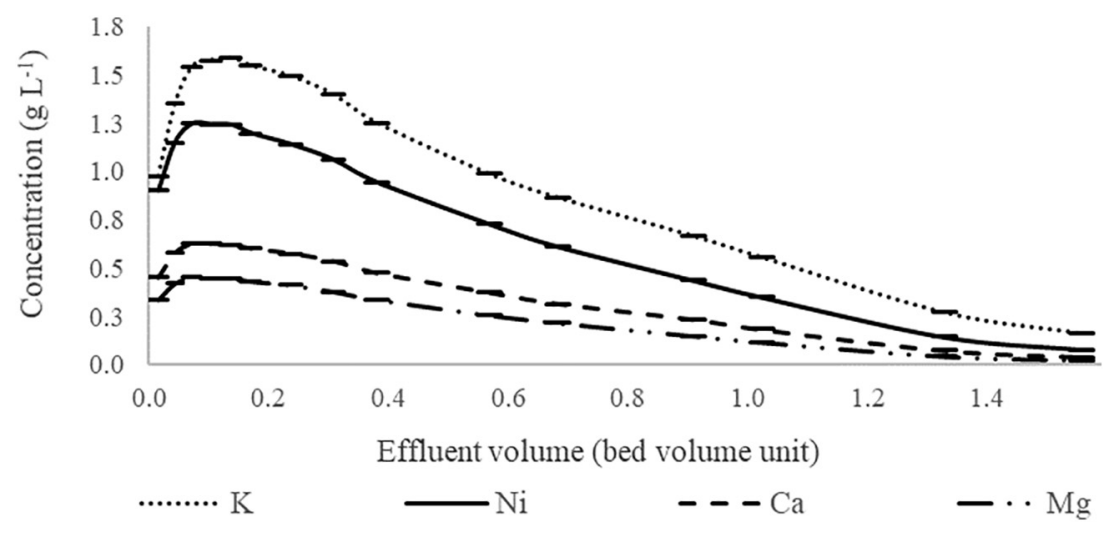

Fig. 3. Evolution of elements concentration $\left(\mathrm{mg} \mathrm{L}^{-1}\right)$ during A. murale column leaching. 


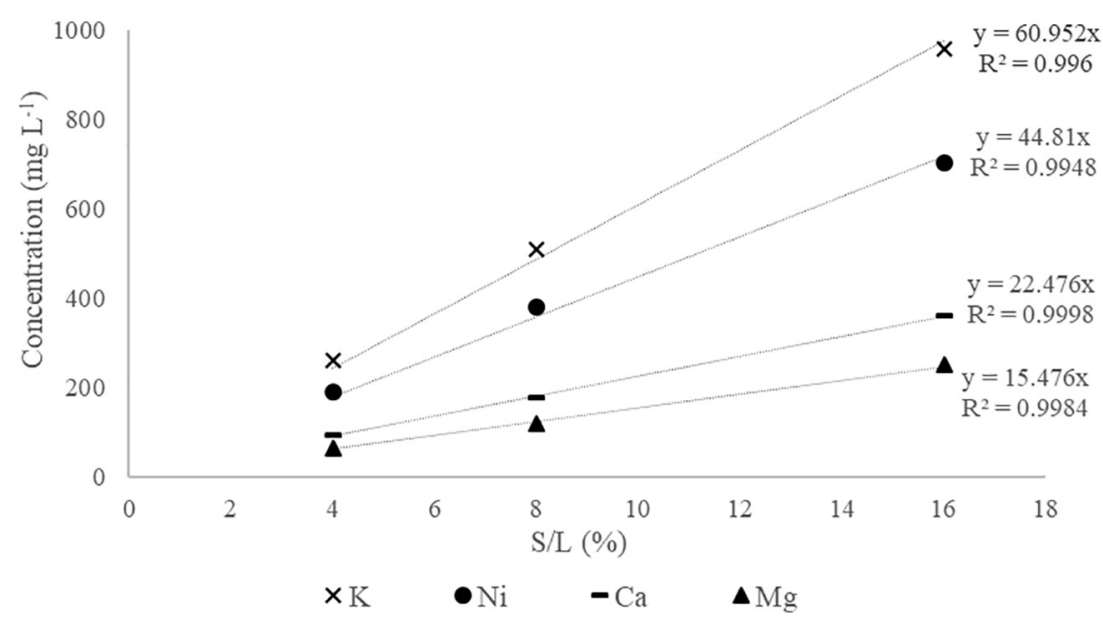

Fig. 4. Concentrations (mg $\mathrm{L}^{-1}$ ) of $\mathrm{K}, \mathrm{Ni}, \mathrm{Ca}, \mathrm{Mg}$ in the leachate against the $\mathrm{S} / \mathrm{L}$ ratio.

$6 \%$ the remaining part being complexed by $\mathrm{Ca}$ and $\mathrm{Mg}(6 \%), \mathrm{Mg}(2 \%)$ and $\mathrm{Ca}(1 \%)$. Minerals anions did not complex with Ni because their formation constants were lower than $\mathrm{Ni}$ carboxylates ones (Martell et al., 1997).

Despite only taking the LMWCAs into account, it is sufficient to explain that almost $100 \%$ of $\mathrm{Ni}$ is complexed, mainly by three acids. The citrate complex is the most stable ( $\log \mathrm{K}=17.23$ ) (Martell et al., 1997), followed by the malonate complex ( $\log K=3.90$ ) (Martell et al., 1997) and the malate complex (log K=3.90) (Martell et al., 1997). Actually, $98 \%$ of the citrate in the leach liquor is complexed with $\mathrm{Ni}$ against only $20 \%$ and $27 \%$ for malate and malonate. These results clearly show that $\mathrm{Ni}$ is never in the $\mathrm{Ni}^{2+}$ form but bound by organic matter.

Results were different for $\mathrm{K}$, Ca and $\mathrm{Mg}$ : $\mathrm{K}$ was mainly in the $\mathrm{K}^{+}$ form (98\%) while ca $20 \%$ of $\mathrm{Ca}$ and $\mathrm{Mg}$ were chelated to malate and $\mathrm{ca}$ $80 \%$ free (supplementary materials S2).

\subsection{Is it possible to recover Ni by selective precipitation?}

Experiments were performed to assess the possibility of recovering $\mathrm{Ni}$ as nickel hydroxide by selective precipitation (section 2.4). No precipitate was obtained, which was consistent with previous results (Barbaroux et al., 2011). In this reference, 14\% of Ni vanished from the leachate, but there was no evidence of hydroxide precipitation. Organic matter could have adsorbed Ni while flocculation had been observed.

The experiments were simulated with Chess, in order to explain the involved processes. The initial composition of the solution is given in Table 3. A pH increase from 2 to 13 was simulated, considering the same equilibria as previously
Table 3

Global leachate concentrations input in Chess to calculate Ni speciation.

\begin{tabular}{llll}
\hline \multicolumn{2}{l}{ Concentration $\left(\mathrm{mmol} \mathrm{L}^{-1}\right)$} & \\
\hline Elements & & Carboxylic acid & \\
\hline $\mathrm{K}$ & 24.64 & Malic acid & 18.93 \\
$\mathrm{Ni}$ & 9.56 & Malonic acid & 11.84 \\
$\mathrm{Ca}$ & 6.97 & Citric acid & 3.61 \\
$\mathrm{Mg}$ & 7.83 & Acetic acid & 2.48 \\
$\mathrm{Fe}$ & 0.02 & Oxalic acid & 1.10 \\
\hline
\end{tabular}

Results are displayed in Fig. 7, exhibiting the variations of the concentrations of the LMWCAs and of the Ni species: the free form $\mathrm{Ni}^{2+}$ was mainly observed at $\mathrm{pH}$ lower than 4 ; from $\mathrm{pH} 3$ to 8 , $\mathrm{Ni}$ was complexed by citrate and malate, and the precipitation of $\mathrm{Ni}(\mathrm{OH})_{2 \mathrm{~s}}$ started from $\mathrm{pH}$ 8.5. Results for $\mathrm{Ca}$ and $\mathrm{Mg}$ are displayed in supplementary S3.

As expected, the $\mathrm{Ni}(\mathrm{OH})_{2 \mathrm{aq}}$ complex was never observed since its formation constant at $25^{\circ} \mathrm{C}\left(\log \mathrm{K}_{1}=12.7485\right)$ is very close to the one of $\mathrm{Ni}(\mathrm{OH})_{2 \mathrm{~s}}\left(\log \mathrm{K}_{2}=12.4719\right)$, corresponding to the equilibria expressed with Eqs. (4 and 5):

$\mathrm{Ni}_{a q}^{2+}+2 \mathrm{OH}_{a q}^{-} \leftrightarrow \mathrm{Ni}(\mathrm{OH})_{2 \mathrm{aq}}$

which formation constant is expressed by Eq. (5):

$\mathrm{K}_{1}=\frac{\left[\mathrm{Ni}(\mathrm{OH})_{2 \mathrm{aq}}\right]}{\left[\mathrm{Ni}_{\mathrm{aq}}^{2+}\right] *\left[\mathrm{OH}_{\mathrm{aq}}^{-}\right]^{2}}$

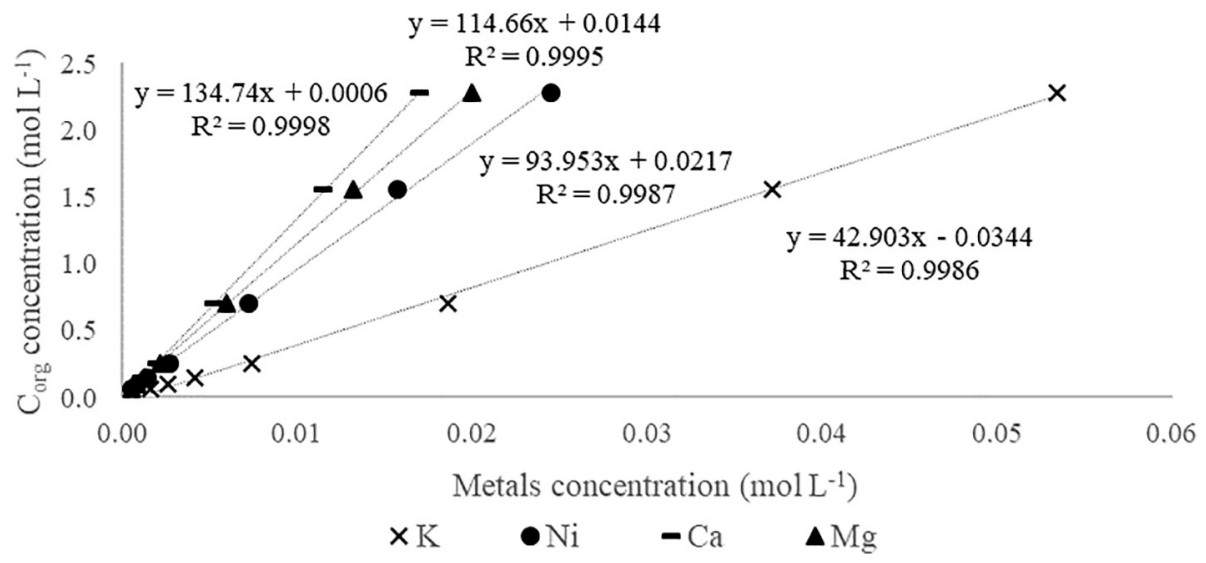

Fig. 5. $\mathrm{C}_{\text {org }}$ concentration plotting against metals concentration $\left(\mathrm{mol} \mathrm{L}^{-1}\right)$. 


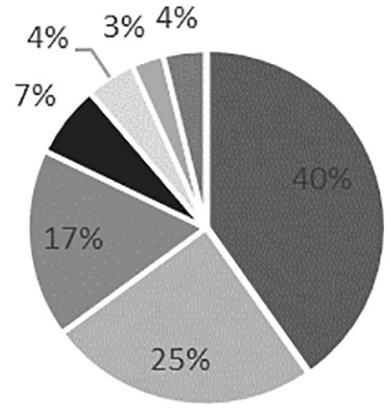

$$
\begin{aligned}
& \square(\text { Malate }) \mathrm{Ni} \quad \square(\text { Malonate }) \mathrm{Ni} \\
& \square(\text { Citrate } 2 \mathrm{Ni}[3-] \quad \square(\text { Oxalate }) \mathrm{Ni} \\
& \square(\text { Malonate } 2 \mathrm{Ni}[2-] \square \mathrm{Ni}[2+] \\
& \square \text { Other complexes }
\end{aligned}
$$

Fig. 6. Ni speciation in global leachate calculated with Chess from data given in Table 2.

$\mathrm{Ni}_{\mathrm{aq}}^{2+}+2 \mathrm{OH}_{\mathrm{aq}}^{-} \leftrightarrow \mathrm{Ni}(\mathrm{OH})_{2 \mathrm{~s}}$

which formation constant is expressed by Eq. (7):

$K_{2}=\frac{1}{\left[N i_{a q}^{2+}\right] *\left[O H_{a q}^{-}\right]^{2}}$

These calculated results were not in agreement with experimental data: the precipitation of $\mathrm{Ni}(\mathrm{OH})_{2}$ was predicted at $\mathrm{pH}$ higher than 8.5, but not observed. This difference can be due to kinetic reasons and/or to the presence of another chelating agent of $\mathrm{Ni}$, which has not been identified yet. To support this assumption, simulations were performed, considering the formation of an additional complex.

Assuming that this complex was formed with monodentate ligands $\left(\mathrm{NiL}_{2}\right)$, this new reaction following Eq. (8), and its formation constant $\mathrm{K}_{3}$ were added into the database:

$\mathrm{Ni}_{\mathrm{aq}}^{2+}+2 \mathrm{~L}_{\mathrm{aq}}^{-} \leftrightarrow \mathrm{NiL}_{2 \mathrm{aq}}$

with its formation constant expressed by Eq. (9):

$K_{3}=\frac{\left[\mathrm{NiL}_{2 \mathrm{aq}}\right]}{\left[\mathrm{Ni}_{\mathrm{aq}}^{2+}\right] *\left[\mathrm{~L}_{\mathrm{aq}}^{-}\right]^{2}}$

The dissociation constant of the ligand was set to $\mathrm{pKa}=0.5$, to ensure that the ligand was always in the deprotonated form $\mathrm{L}^{-}$.

Then, simulations were run with different values of $\log \mathrm{K}_{3}$, considering an excess of ligand compared to $\mathrm{Ni}\left(\left[\mathrm{Ni}^{2+}\right]=10 \mathrm{mM}\right.$, $\left[\mathrm{L}^{-}\right]=30 \mathrm{mM}$ ). The results are shown in Fig. 8, for six values of $\log \mathrm{K}_{3}$ $(1,4,5,8,10,15)$. For $\log \mathrm{K}_{3}=1$, no $\mathrm{NiL}_{2}$ is formed and Ni hydroxide precipitation starts from $\mathrm{pH}$ 7.5. If $\log \mathrm{K}_{3}$ is increased to 4 and $5, \mathrm{NiL}_{2}$ complexation occurs but $\mathrm{Ni}$ is not totally complexed
$\left(\left[\mathrm{NiL}_{2}\right]<10 \mathrm{mmol} \mathrm{L}^{-1}\right.$ ) and $\mathrm{Ni}$ hydroxide precipitation is slightly shifted to higher $\mathrm{pH}$, respectively 7.8 and 8.0. For $\log \mathrm{K}_{3}$ equal or higher than $8, \mathrm{Ni}^{2+}$ is totally complexed at low $\mathrm{pH}$ and Ni hydroxide is significantly shifted to higher $\mathrm{pH}$ or even inhibited. In other words, in the presence of a strong chelating agent, the precipitation of $\mathrm{Ni}(\mathrm{OH})_{2(\mathrm{~s})}$ occurred at higher $\mathrm{pH}$ or was prevented. Similar results were obtained by considering a monodentate ligand (to obtain a NiL complex). Therefore, the presence of a strong chelating agent $\left(\log K_{3}>8\right)$ in the plant leachate could explain that nickel hydroxide did not precipitate by increasing the $\mathrm{pH}$. These results also indicate that such a chelating agent coated on a resin should enable us to recover Ni from the leachate.

\section{Conclusion}

This contribution has clearly shown that $\mathrm{Ni}$ could be extracted from dry hyperaccumulator plants by water leaching at $20^{\circ} \mathrm{C}$. No acid or complexing agent is required. Two contrasted hyperaccumulators $(A$. murale and $R$. bengalensis) belonging to very different families were compared. The highest extraction yield was reached with A. murale, because of the more superficial localization of $\mathrm{Ni}$ in its tissues. The other main elements $(\mathrm{K}, \mathrm{Ca}, \mathrm{Mg})$ were also transferred into the solution as well as dissolved organic matter. The characterization of the solution showed that LMWCAs were present. Simulations of speciation at equilibrium indicated that $\mathrm{Ni}$ was chelated by these LMWCAs, like in the plant tissues. If $\mathrm{Ni}$ was only bound to these acids, it could be recovered by selective precipitation of $\mathrm{Ni}$ hydroxide. However, experimentally, precipitation failed, suggesting that $\mathrm{Ni}$ could be partly bound to a stronger ligand, the logarithm of the formation constant of the complex being at least equal to 15 .

From a scientific point of view, this work has brought a better understanding of the chemical equilibria governing the composition of the leachate, which should be of great help to explore the strategies for $\mathrm{Ni}$ recovery in valuable forms. The methodology is quite general and can be applied to a variety of other hyperaccumulators and elements. Considering practical applications, the total chain must be developed in order to assess its global efficiency, cost and environmental impacts that will be compared to the processes involving ashing.

\section{Acknowledgement}

This work was supported by the French National Research Agency through the ANR-14-CE-04-0005 Project "Agromine" and by the French ministry of higher education and research. The work is also a contribution to the French National Research Agency through the national "Investissements d'avenir" program (ANR-10-LABX-21 - LABEX RESSOURCES21). The authors are grateful to Pr A. Bani (UAT, Albania) for providing A. murale, biomass and to $\mathrm{M}$. Richard Ismane of Monggis village where $R$. bengalensis was sampled, and are debtful to Dr. van der Ent for having created the conditions for the collaboration with Sabah Parks (Malaysia) and to M. Sukaibin Sumail (Sabah Parks, Malaysia) for his continuous support to improve knowledge and applications about

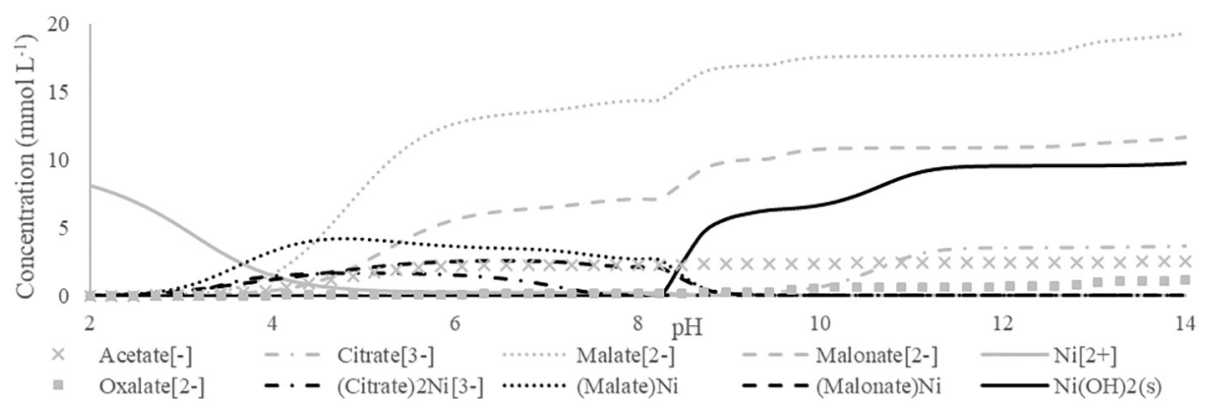

Fig. 7. Modeling of Ni speciation during $\mathrm{pH}$ increase simulation (Chess). 

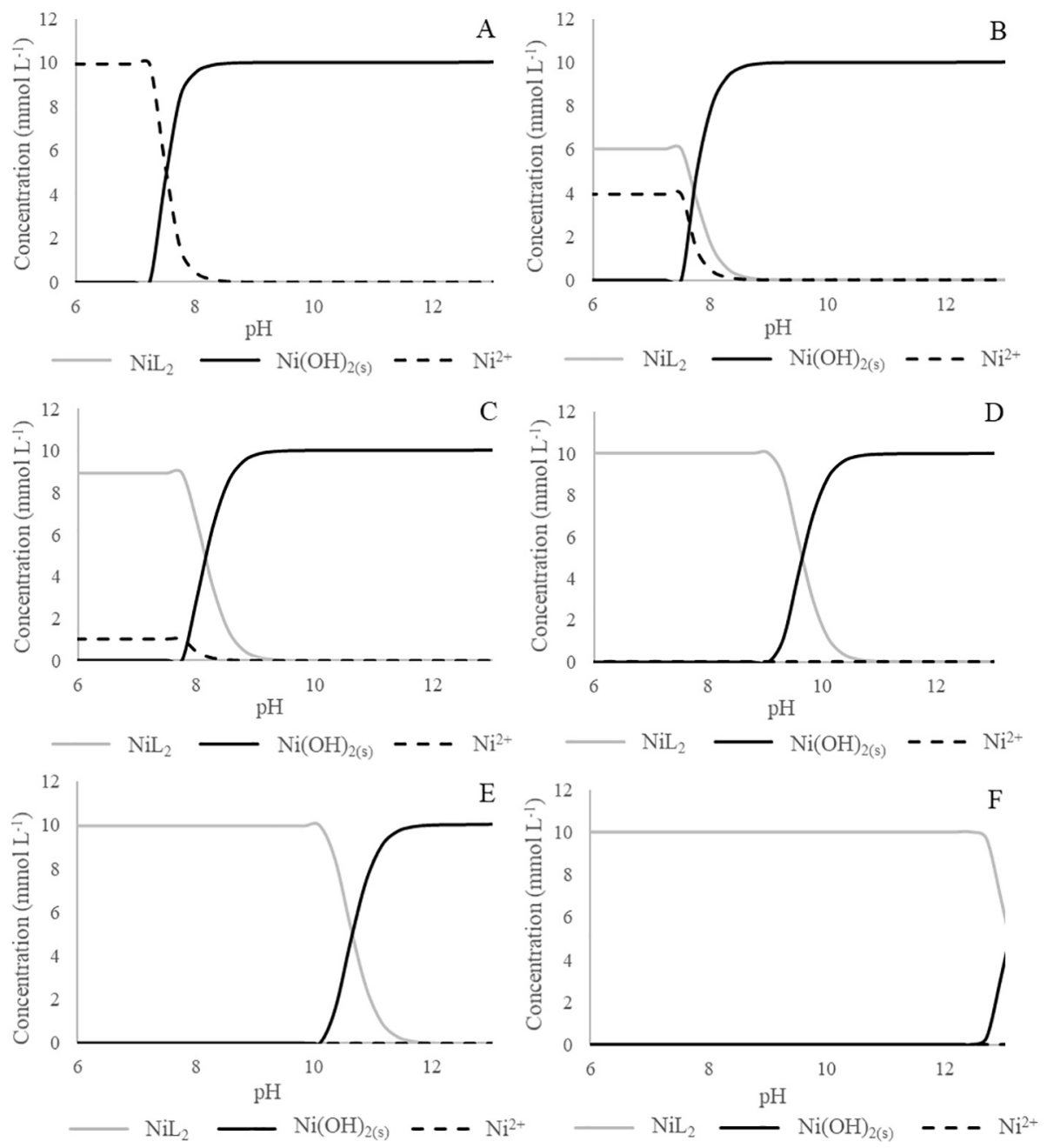

Fig. 8. Ni speciation against $\mathrm{NiL}_{2}$ formation constant variation.

tropical hyperaccumulator plants. They authors wish to thank the GISFI and the STEVAL platform and technical staff for the pre-processing of the plant biomass.

\section{Appendix A. Supplementary data}

Supplementary data to this article can be found online at https:// doi.org/10.1016/j.hydromet.2018.07.024.

\section{References}

Alves, S., et al., 2011. Nickel speciation in the xylem sap of the hyperaccumulator Alyssum serpyllifolium ssp. lusitanicum growing on serpentine soils of Northeast Portugal. J. Plant Physiol. 168 (15), 1715-1722.

Bani, A., et al., 2010. Nickel hyperaccumulation by the species of Alyssum and Thlaspi (Brassicaceae) from the ultramafic soils of the Balkans. Bot. Serb. 34 (1).

Bani, A., et al., 2013. Nickel hyperaccumulation in the serpentine flora of Albania. Fresenius Environ. Bull. 22 (6), 1792-1801.

Bani, A., et al., 2015. Improving the agronomy of Alyssum murale for extensive Phytomining: a five-year field study. Int. J. Phytoremediat. 17 (2), 117-127.

Barbaroux, R., et al., 2009. Chemical leaching of nickel from the seeds of the metal hyperaccumulator plant Alyssum murale. Hydrometallurgy 100 (1), 10-14.

Barbaroux, R., et al., 2011. A new method for obtaining nickel metal from the hyperaccumulator plant Alyssum murale. Sep. Purif. Technol. 83, 57-65.

Barbaroux, R., et al., 2012. A new process for nickel ammonium disulfate production from ash of the hyperaccumulating plant Alyssum murale. Sci. Total Environ. 423, 111-119.

Broadhurst, C.L. et al., 2004. Nickel localization and response to increasing Ni soil levels in leaves of the Ni hyperaccumulator Alyssum murale. Plant Soil 265 (1), 225-242.

Callahan, D.L., et al., 2006. Metal ion ligands in hyperaccumulating plants. J. Biol. Inorg. Chem. 11 (1), 2-12.

Centofanti, T., et al., 2013. Xylem exudate composition and root-to-shoot nickel translocation in Alyssum species. Plant Soil 373 (1), 59-75.

Chaney, R.L., et al., 2007. Improved understanding of hyperaccumulation yields commercial phytoextraction and phytomining technologies. J. Environ. Qual. 36 (5), 1429-1443.

Chaney, R.L., et al., 2018. The long road to developing agromining/phytomining. In: Van der Ent, A., Echevarria, G., Baker, A.J.M., Morel, J.L. (Eds.), Agromining: Farming for Metals: Extracting Unconventional Resources Using Plants. Springer International Publishing, Cham, pp. 1-17.

Furia, T.E., 1973. CRC Handbook of Food Additives, 1. CRC press.

Galey, M., et al., 2017. Ultramafic geoecology of South and Southeast Asia. Bot. Stud. Int. J. 58 (1), 18.

Grison, C., et al., 2013. Psychotria douarrei and Geissois pruinosa, novel resources for the plant-based catalytic chemistry. RSC Adv. 3 (44), 22340-22345.

Houzelot, V., et al., 2017. Effect of up-scaling on the quality of ashes obtained from hyperaccumulator biomass to recover Ni by agromining. Chem. Eng. Res. Des. 120, 26-33.

Houzelot, V., et al., 2018. Agromining of hyperaccumulator biomass: study of leaching kinetics of extraction of nickel, magnesium, potassium, phosphorus, iron, and manganese from Alyssum murale ashes by sulfuric acid. Chem. Eng. Res. Des. 129, 1-11.

Kersten, W.J., et al., 1980. Nature of nickel complexes in psychotria douarrei and other nickel-accumulating plants. Phytochemistry 19 (9), 1963-1965.

Kidd, P., et al., 2015. Agronomic practices for improving gentle remediation of trace element-contaminated soils. Int. J. Phytoremediat. 17 (11), 1005-1037.

Li, Y.-M., et al., 2003. Development of a technology for commercial phytoextraction of nickel: economic and technical considerations. Plant Soil 249 (1), 107-115.

Martell, A., et al., 1997. Critically Selected Stability Constants of Metal Complexes Database. (College Station TX)

McNear Jr., D.H., et al., 2010. The hyperaccumulator Alyssum murale uses complexation with nitrogen and oxygen donor ligands for Ni transport and storage. Phytochemistry 71 (2-3), 188-200.

McNear, D.H., et al., 2005. Application of quantitative fluorescence and absorption-edge computed microtomography to image metal compartmentalization in alyssum murale. Environ. Sci. Technol. 39 (7), 2210-2218.

Montargès-Pelletier, E., et al., 2008. Identification of nickel chelators in three hyperaccumulating plants: an X-ray spectroscopic study. Phytochemistry 69 (8), 
1695-1709.

Morel, J.L., 2013. Using Plants to "Micro-Mine". http://www.inra.fr/en/ScientistsStudents/Biomass/All-the-news/Using-plants-to-micro-mine-metals.

Morel, J.L., et al., 2018. Conclusions and outlook for agromining. In: Van der Ent, A., Echevarria, G., Baker, A.J.M., Morel, J.L. (Eds.), Agromining: Farming for Metals: Extracting Unconventional Resources Using Plants. Springer International Publishing, Cham, pp. 309-312.

Nkrumah, P.N., et al., 2018. Agronomy of 'metal crops' used. In: Van der Ent, A., Echevarria, G., Baker, A.J.M., Morel, J.L. (Eds.), Agromining: Farming for Metals: Extracting Unconventional Resources Using Plants. Springer International Publishing, Cham, pp. 19-38.

Simonnot, M.-O., et al., 2018. Processing of bio-ore to products. In: Van der Ent, A., Echevarria, G., Baker, A.J.M., Morel, J.L. (Eds.), Agromining: Farming for Metals: Extracting Unconventional Resources Using Plants. Springer International Publishing, Cham, pp. 39-51.

Van der Ent, A., Mulligan, D., 2015. Multi-element concentrations in plant parts and fluids of Malaysian nickel hyperaccumulator plants and some economic and ecological considerations. J. Chem. Ecol. 41 (4), 396-408.
Van der Ent, A., et al., 2015. Agromining: farming for metals in the future? Environ. Sci. Technol. 49 (8), 4773-4780.

Van der Ent, A., et al., 2017a. Nickel biopathways in tropical nickel hyperaccumulating trees from Sabah (Malaysia). Sci. Rep. 7, 41861.

Van der Ent, A., et al., 2017b. Agromining: Farming for Metals: Extracting Unconventional Resources Using Plants. Springer.

Van der Lee, J., De Windt, L., 2002. Chess Tutorial and Cookbook. Updated for Version 3.0. Ecole Nationale Supérieure des Mines de Paris, Fontainebleau, France, Technical Report n LHM/RD/02/13. http://chess.geosciences.mines-paristech.fr.

Vaughan, J., et al., 2017. Characterisation and hydrometallurgical processing of nickel from tropical agromined bio-ore. Hydrometallurgy 169, 346-355.

Verbruggen, N., et al., 2008. Molecular mechanisms of metal hyperaccumulation in plants. New Phytol. 181 (4), 759-776.

Zhang, X., et al., 2014. Selection and combustion of Ni-hyperaccumulators for the phytomining process. Int. J. Phytoremediat. 16 (10), 1058-1072.

Zhang, X, et al, 2016. Increasing purity of ammonium nickel sulfate hexahydrate and production sustainability in a nickel phytomining process. Chem. Eng. Res. Des. 106, 26-32. 